\title{
THE EFFECT OF CURRICULUM 2013 ON ECONOMICS LEARNING ACHIEVEMENT: MOTIVATION AS MEDIATING VARIABLE
}

\author{
Ananda Setiawan $^{1,2 *}$, Sri Umi Mintarti Widjaja ${ }^{2}$, Djoko Dwi Kusumajanto ${ }^{2}$, Hari Wahyono ${ }^{2}$ \\ ${ }^{1}$ Lambung Mangkurat University, Indonesia \\ ${ }^{2}$ Malang State University, Indonesia \\ *e-mail: ananda.setiawan@ulm.ac.id
}

\begin{abstract}
The National Standard of Education (NSE) in Indonesia is a legitimate instrument to reach the best achievement. Yet, there are still the other positive factors, especially on economics subjects. This research aimed to find out the direct effect of the national standard of education (NSE) involving in a standard of content (SC), standard for educator and education staff (SEE), standard of facilities (SF), standard of assessment (SA), standard of the process (SP) and competence graduate standard (CGS) on achievement motivation (AM) and economics learning achievement (ELA), and to find out the indirect influence of SC, SEE, SF, SA, SP, and CGS on ELA through AM. This descriptive quantitative research used a survey to collect the data. The population is Indonesian senior high school students who have learned the economy for, at least. A total of 1065 students were selected through using proportional stratified random sampling with the Slovin formula (error $=1 \%$ ). The data in this study were collected through The data were subsequently analyized using Structural Equation Modeling (Partial Least Square approach). The result of this research showed that there was a direct effect of SC, SEE, SF, SA, SP, and CGS and AM on ELA. Then, there was an indirect effect of SC, SEE, SF, SA, and CGS on ELA through $\mathrm{AM}$ as a mediating variable.
\end{abstract}

\section{Keywords: curriculum, achievement, motivation, the national standard of education}

\section{PENGARUH KURIKULUM 2013 PADA PENCAPAIAN PEMBELAJARAN EKONOMI: MOTIVASI SEBAGAI VARIABEL MEDIASI}

\begin{abstract}
Abstrak: Standar Nasional Pendidikan di Indonesia adalah alat yang pasti untuk menunjukkan capaian yang terbaik. Namun, ada banyak faktor positif lainnya, khususnya dalam bidang ekonomi. Tujuan dari penelitian ini adalah untuk mengetahui pengaruh langsung pada standar nasional pendidikan (SNP) yang terdiri dari standar isi (SI), standar pendidik dan tenaga kependidikan (SPP), standar fasilitas (SF), standar penilaian (SP), standar proses (SPr) dan standar kompetensi lulusan (SKL) pada motivasi berprestasi (MB) dan prestasi belajar ekonomi (PBE) melalui MB, dan untuk mengetahui pengaruh tidak langsung antara SI, SPP, SF, SP, SPr dan SKL pada PBE. Penelitian ini adalah penelitian deskriptif kuantitatif dengan metode survei. Populasinya adalah siswa sekolah menengah atas setelah belajar ekonomi, setidaknya selama satu tahun. Sampel adalah 1065 siswa dengan menggunakan proportional stratified random sampling dengan rumus Slovin (error $=1 \%$ ). Teknik pengumpulan data penelitian dengan menggunakan kuesioner dan dokumen yang valid dan reliabel. Analisis data menggunakan Structural Equation Modeling (pendekatan Partial Least Square). Hasil penelitian ini menunjukkan bahwa ada pengaruh langsung antara SI, SPP, SF, SP, SPr dan SKL dan MB pada PBE. Kemudian, terdapat efek tidak langsung antara SI, SPP, SF, SP, dan SKL pada PBE melalui MB sebagai variabel moderasi.
\end{abstract}

Kata Kunci: kurikulum, prestasi, motivasi, standar nasional pendidikan

\section{INTRODUCTION}

The achievement on institutional education is affected by supporting educational components. One of the components is Curriculum. The Curriculum had been developed onto whole educational elements based on the current needs and challenge in this world. Indonesia has the first Curriculum, Curriculum 1947. By the time, it, then, has developed based on period, Curriculum 1964, Curriculum 1968, Curriculum 1973, Curriculum 1975, Curriculum 1984, Curriculum 1994, Curriculum 1997, 
Curriculum 2004, Curriculum 2006, Curriculum 2013, Curriculum 2013 (revision) and until national Curriculum.

In the implementation, however, some curricula were applied based on the school authority and stuff. One of the curricula temporarily used is Curriculum $13(\mathrm{~K}-13)$. The Curriculum itself began as a Latin word currere, which means the yard of a race. Saylor \& Alexander (1974) stated that curriculum broadly defines as a reflection of assessing volume about assessment property. This definition also affects how the curriculum will be playable and profitable. Ornstein \& Hunkins (2013) said that the Curriculum is a confusing, difficult, and fragment study to understand. The curriculum involves the whole stakeholder, of course, teachers and students, in line with this theory. Shawer (2017) explained that the Curriculum is altogether creating corporately a good person, both teacher and student.

Besides of Bussmaker, Trokanas \& Franjo (2017) said that knowledge needed in the curriculum is very large for teachers to maintain gradually a developed Curriculum. Then, according to Moss \& Harvie (2015), the definition of classic curriculum is also for principle, students, and policymakers. Law number 20 in 2003 about the National Education System and Rule of Indonesia Government no. 19 in 2005 about the National Standard of Education (NSE) explained that curriculum is a set of plans and a set of purpose, content, teaching materials, and the method as a basic guideline of learning to reach the goal of education. Then, curriculum raises issues concerning students of control and power over the learning process, that conditions will give achievement and enjoyment of learning for students (Hopkins, 2008; Robinson \& Fieldling, 2010; Robinson, 2014; Hargreaves, 2017; Manyukhina \& Wyse, 2019).

Short (1987) stated that curriculum scope is policymaking, development, evaluation, change, decision making, activity or study field, and form and investigation language. According to Hargreaves \& Moore (2000) described that many theoretical discussions about curriculum have been separated from practical in the class, and many practical discussions about curriculum rarely consider the theoretical connection. The Curriculum 2013 (K-13) is the one based on competence designed to anticipate what people need in this 21 st century. K-13 aims to create creative effective productive people by attitude, skill, and knowledge (Mulyasa, 2014).

Similarly, the objective of K-13 is to prepare Indonesian in order to be better ones who have a good belief, and become productive, creative, innovative, effective and afford to contribute what they can do in social, national and statue life, and in civilization (Ministry of Education Law No.70 Year 2013). Hosnan (2016) said that scientific learning is instead of 5 steps, observing, questioning, associating, experimenting, and networking. There are schools that have not yet provided counseling guidance services.

A few problems found in research field namely education has not provided maximum academic service, school ventilation systems have not been functioning optimally, textbook needs are incomplete, there are students who do not have a high level of confidence, there are students who are not responsible for their learning duties, teacher Unpreparedness employs an interactive learning method that is required in K-13 and low motivation for achieving students.

Standard of content (SC) is a criterion about learning material and competency level to reach a minimum standard of competence on one level and type (Mulyasa, 2014). Standard of the process (SP) is a criterion about organizing the learning in education to reach that standard itself. Competence graduate standard (CGS) is a criterion about qualification on students' ability to pass the minimum standard, instead of, affective, cognitive, and psychomotor. Standard of educator and education staff (SEE) is a criterion about positional educational level, both worth on mental, and education on one level. Standard of the facility (SF) is a criterion on the place to study, to the sport, the library, the worship place, laboratory, the place to play, and supporting things to espouse to the learning process (Mulyasa, 2014). Then, the facility of education as like online facility and offline facility or blended learning, facility of education is very important to improve the learning outcome of Senior High School Students (Sari \& Setiawan, 2018).

Education financing standard (EFS) is a criterion about component and operational cost in education in one year. Standard of assessment (SA) is a criterion about the mechanism, procedure, and instrument to assess the students' 
achievement. One of the assessments is by giving them an exam. It is done to measure the achievement of students' competence (Mulyasa, 2014). Singh (2011) Achievement motivation (AM) is a will to do the best on those standardizations. Motivation is likely related to academic things, cognitive, emotion, and indicator of students' in education (Tucker, Zayco, \& Herman, 2002). Motivation is the study of why humans think, feel, and behave (Wood \& Graham, 2015). Most of the shows there is a very strong relationship between motivation there is learning success and academic achievement (Corpus, McClintic-Gilbert, \& Hayenga, 2009). Motivation can also be defined as a plan or a wish to head towards success and avoid failure (Papilaya, Tuakora, \& Rijal, 2019). The findings revealed that the achievement motivation moderated the relationship of learning approaches and academic achievement significantly $(p<$ .05) (Bakhtiarvand, Ahmadiana, Delrooza \& Delrooza, 2011), and there is a relationship between achievement motivation and performance (Hardin, Mustari, \& Sari, 2019). But there has been no previous research that makes achievement motivation as a moderating variable between curriculum implementation of economics learning outcomes.

Implementing the curriculum according to the plan will produce good learning outcomes. However, there need to be other endeavors outside the curriculum instrument to support learning outcomes. one that can be maximized is student achievement motivation. Winkel (2004) explains that students' achievement is the result given to the students themselves. Cognitive learning includes knowledge, comprehension, application, analysis, synthetic, and evaluation. In addition, the object of the effective involves five levels: accept, respond, assess, organize, and characterize. Lastly, the object of psychomotor is a reflex and basic movement, perception skill, physical ability, skilled movement, and no discursive communication (Ornstein \& Hunkins, 2013).

As mentioned, the National Standard of Education (NSE) in Indonesia is a legitimate instrument to reach the best achievement. Yet, there are still other positive factors to students' achievement, especially on economics subjects. One of them is AM. AM is a desire to do well relative to some standard of excellence (Singh, 2011). It has been assigned as a reference for a different need in each people to achieve appreciation like satisfaction, praise from other people, and self-satisfaction (McClelland, 1985).

This research aimed to find out the direct effect on the national standard of education (NSE) involving in a standard of content (SC), standard for educator and education staff (SEE), standard of facilities (SF), standard of assessment (SA), standard of the process (SP) and competence graduate standard (CGS) on achievement motivation (AM) and economics learning achievement (ELA), and to find out the indirect influence between SC, SEE, SF, SA, SP, and CGS on ELA through AM.

\section{METHODS \\ Research Design}

This research was conducted in senior high school which has been applied K-13, taking the place in Serdang Bedagai district, North Sumatera, Indonesia. Implementation of $\mathrm{K}-13$ in some districts instead of eight NSE that has been assigned by the Government, those are SC, SP, CGS, SEE, SF, MS, EFS, and SA. However, in this research, these variables did no longer exist as a whole. The researcher only focused on NSE in K-13, SC, CGS, SEE, SF, $\mathrm{SP}$, and SA (exogenous variable) and AM and ELA (endogenous variable). Analysis data was by using Structure Equation Modeling-Partial Least Square (SEM-PLS). SEM-PLS has the advantage of analysis that is data does not have to be normally distributed. Therefore, this study does not test data normality and linearity. The conceptual model was being applied (see Figure $1)$.

\section{Population and Sampling}

The population in this research was state high school students which were applied K-13 in their schools and for them who have learned economics, at least, for one year in some districts whose total was 1192 students, at the time of the survey. The respondent was in the 11th and 12th grades. This research used a quantitative descriptive through the survey method. The sample was 1065 students by proportional stratified random sampling technique with Slovin's formula $($ error $=1 \%)$. 


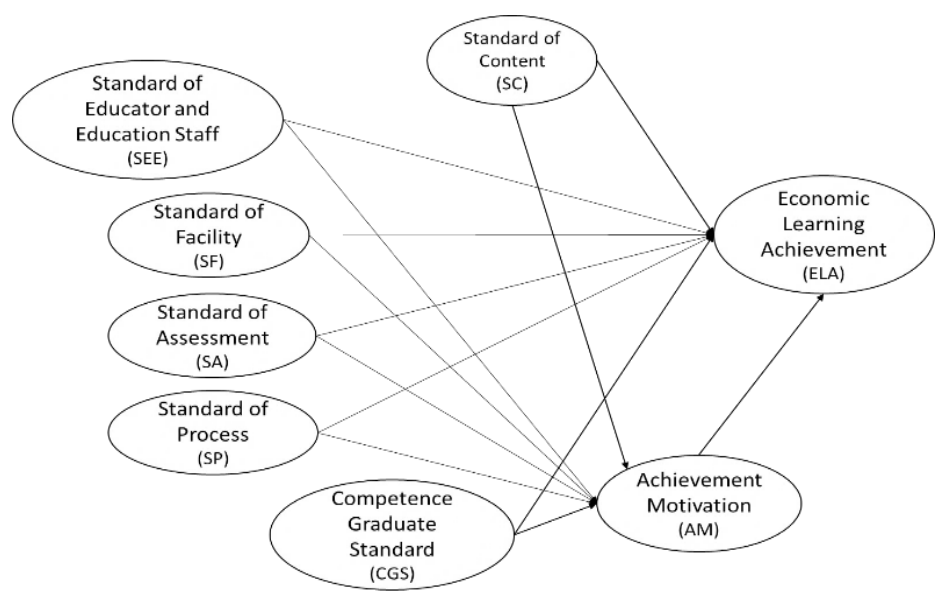

Figure 1. Conceptual Model

\section{Instrument and Measurement}

The instrument in this research is to measure SC, CGS, SEE, SF, SP, SA, and AM by using questionnaires. Participant responses to items use a 7-point continuous scale $(1=$ strongly disagree to $7=$ strongly agree). The questionnaires were developed from the national standard of education (Government regulation number 32 in 2013; Poerwati \& Amri, 2013). The instrument was developed from variables because similar instruments had never existed.

The statement which is used inside was easy to understand for the respondent. After that, the instrument of ELA was used to the final score, it was categorized, then (1 to 7). ELA was divided into 3, knowledge about economics, attitude, and skill (Bussmaker et al., 2017; Kurniasih \& Sani, 2014). The result was taken from the final score in the class when it had been categorized.

\section{Validity for a Research Instrument}

Convergent validity relating to the measurement is a value of loading factor (LF) with the rule of thumb $>.7$, LF value $>.7$ is ideal which means the indicator is valid. The result of the questionnaire test could be described in Figure 2. It shows that the whole instrument could be regarded as a valid instrument because of the LF value known through data tabulation.

\section{Reliability of Research Instrument}

The reliability test can be viewed on the value of Cronbach's alpha and composite reliability (CR) or well-known as DillonGoldstein's. Rule of thumb which can be used to measure the reliability by the value of CR >
.7 for confirmatory research and value of CR $.6-.7$ could be said as reliable to measure the reliability of explanatory research. Then, the value of the average variance extracted (AVE) is more than .5 (Haryono, 2017). The reliability constructs. To check the reliability construct can be used convergent validity based on reliability result for each variable. See Table 1.

Table 1 shows the Cronbach's alpha values $>.7, \mathrm{CR}>.7$, and AVE $>.5$. So these results indicate that all research variables can be said to be reliable and can be used as research instruments. The validity and reliability show that the instruments built have a quality that can be accounted for as research instruments.

\section{FINDINGS AND DISCUSSION Findings \\ Evaluation of Measurement Model}

The entire variable has reflexive indicators which, then, are validated by using the value of discriminant validity. After all, to test the reliability one variable can use convergent validity by $\mathrm{CR}$ values, Cronbach's Alpha, AVE value, and compare the root value of AVE by correlation-construct.

\section{Construct Validity Test}

The questionnaire of the research can be valid or can be used in this research if the LF value more than .7 (Haryono, 2017). Parameter of the validity-convergent test in the measurement model by using reflexive indicators so the LF value $>.7$ can be used (Haryono, 2017). Based on Figure 3 describes that the entire research questionnaire was valid. It could be viewed by the entire items showing that $L F$ value $>.5$. 


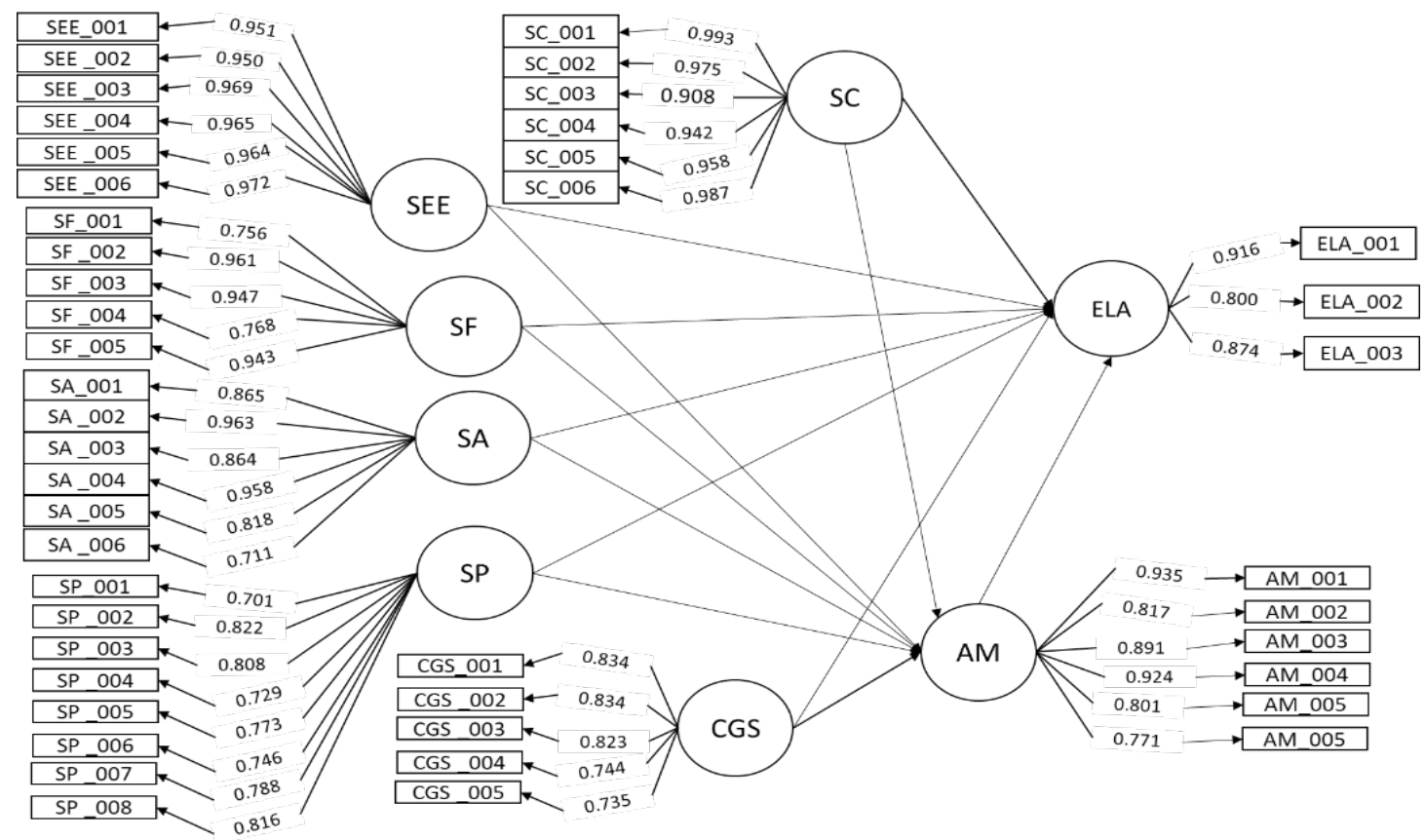

Figure 2. Algorithm Result

Table 1. Reliability

\begin{tabular}{ccccc}
\hline No & Constructs & Cronbach's Alpha & CR & AVE \\
\hline 1 & SC & .983 & .957 & .923 \\
2 & SEE & .984 & .898 & .925 \\
3 & SF & .928 & .986 & .774 \\
4 & SA & .933 & .897 & .752 \\
5 & SP & .903 & .948 & .598 \\
6 & CGS & .854 & .922 & .632 \\
7 & AM & .946 & .987 & .787 \\
8 & ELA & .831 & .944 & .747 \\
\hline
\end{tabular}

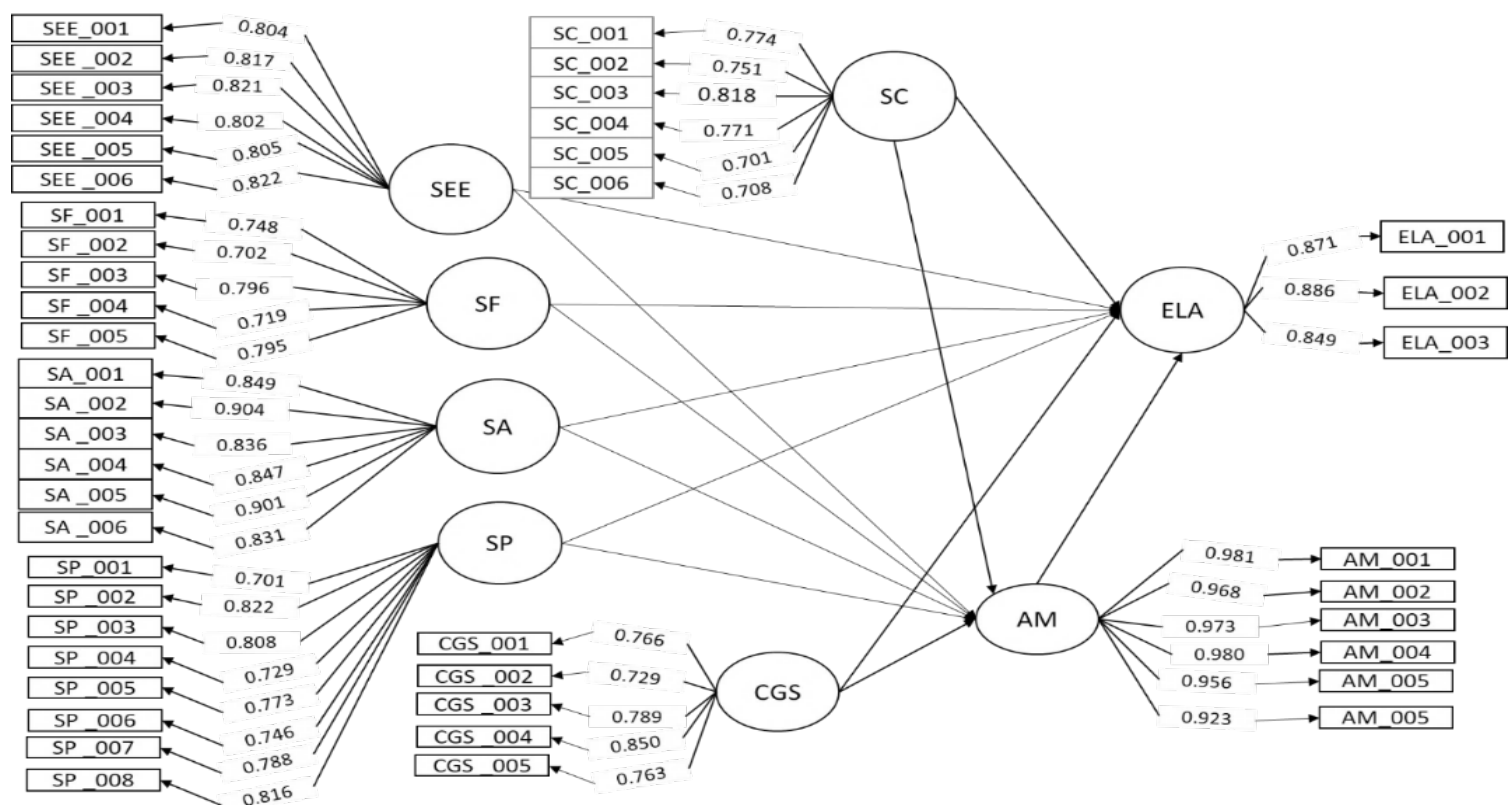

Figure 3. Algorithm Result 


\section{Reliability Testing of Research Construct}

Convergent validity test was done to find out the reliability of one research construct. Evaluation for reliability-construct value could be measured by composite reliable, cronbach's alpha, AVE value (Average Variance Extracted) and compare the AVE root value to the correlation among the construct. Cronbach's alpha value and composite reliability value more than .7 and have AVE value more than .5 can be said as reliable (Haryono, 2017). Result of construct reliability test based on convergent validity shows SC (cronbach's alpha $=.833 ; \mathrm{CR}=.876 ; \mathrm{AVE}=$ .544 ), SEE (cronbach's alpha $=.897 ; \mathrm{CR}=.921$; $\mathrm{AVE}=.659), \mathrm{SF}$ (cronbach's alpha $=.810 ; \mathrm{CR}$ $=.867 ; \mathrm{AVE}=.567), \mathrm{SA}$ (cronbach's alpha $=$. 931; $\mathrm{CR}=.945 ; \mathrm{AVE}=.743)$, SP (cronbach's alpha $=.985 ; \mathrm{CR}=.988 ; \mathrm{AVE}=.930, \mathrm{CGS}$ (cronbach's alpha $=.870 ; \mathrm{CR}=.898 ; \mathrm{AVE}=$ .527 ), AM (cronbach's alpha $=.717$; $\mathrm{CR}=.815$; AVE $=.472$ ), ELA (cronbach's alpha $=.827$; $\mathrm{CR}=.897 ; \mathrm{AVE}=.743)$. That result data showed that the entire research construct is reliable and worthy to hypothesis test. Reliability test, then, is to evaluate Discriminant validity (DV) which involves Cross Loading (CL) and compare to coefficient value of indicator correlation or question item in to construct block by correlated coefficient on the other column (Haryono, 2017).

Each result of output cross-loading can be viewed in appendix 2. The construct research result of output cross-loading showed that each construct has a questionnaire item more than the construct itself. Therefore, it can conclude that each questionnaire item becomes the indicator of the construct itself. After having the result of output cross-loading on the whole fit construct. The next testing is to compare AVE root value to correlation among constructs. The comparative value is shown in Table 2 and Table 3.

Based in Table 2, the comparative value of AVE and the root value of AVE on Table 3 latent variable correlation can be explained that AVE root value is for the whole construct, SC, SEE, SF, SA, SP, CGS, AM, and ELA more than other construct coefficient correlated value. It showed that the requirements of discriminant validity have been completely fulfilled.

Table 2. Comparative AVE and Root of AVE

\begin{tabular}{cccc}
\hline No & Construct & AVE & Root of AVE \\
\hline 1 & SC & .544 & .737521669 \\
2 & SEE & .659 & .811836181 \\
3 & SF & .567 & .752762676 \\
4 & SA & .743 & .861820088 \\
5 & SP & .930 & .964613967 \\
6 & CGS & .527 & .726088832 \\
7 & AM & .472 & .686690067 \\
8 & ELA & .743 & .861993604 \\
\hline
\end{tabular}

Table 3. Latent Variables Correlation

\begin{tabular}{ccccccccc}
\hline Code & SC & SEE & SF & SA & SP & CGS & AM & ELA \\
\hline SC & 1.000 & --- & --- & --- & --- & --- & --- & -- \\
SEE & .598 & 1.000 & --- & --- & --- & --- & --- & --- \\
SF & .583 & .526 & 1.000 & --- & --- & --- & --- & --- \\
SA & .424 & .441 & .396 & 1.000 & --- & --- & --- & --- \\
SP & .417 & .408 & .402 & .671 & 1.000 & --- & --- & --- \\
CGS & .660 & .717 & .675 & .555 & .516 & 1.000 & --- & --- \\
AM & .657 & .701 & .560 & .457 & .417 & .749 & 1.000 & --- \\
ELA & .608 & .632 & .597 & .610 & .515 & .694 & .611 & 1.000 \\
\hline
\end{tabular}




\section{Evaluation of Structural Model}

Evaluation of structural model will be analyzed through the significant value of relation among construct showed by $t$ statistic value on to output coefficients which should be more than 1.96 , then model evaluation also can be said as fit if it has $p$-value $\leq .05$. The value is a basic to hypothesis test by viewing how many quantities of correlation among exogenous construct is to endogenous construct is. $t$ statistic value and $p$-value are showed by output path coefficients by using SmartPLS 3.0. It is shown in Table 4. Based on Table 4 showed that from 13 lines are insignificance at all. Then, based on the test, the hypothesis test can be conducted. The line analysis can be seen in Figure 4.
Figure 4 model estimation among variables of the result of the line analysis calculation. Next on, based on the coefficient value, it can be written the estimation of the structural equation from each substructural below:
a. $\mathrm{AM}=.289 \mathrm{SC}+.414 \mathrm{SEE}+.135 \mathrm{SF}+.145 \mathrm{SA}$ $+.342 \mathrm{SP}+.453 \mathrm{CGS}+\varsigma 1$
b. $\mathrm{ELA}=.547 \mathrm{SC}+.497 \mathrm{SEE}+.370 \mathrm{SF}+.278 \mathrm{SA}$ $+.255 \mathrm{SP}+.177 \mathrm{CGS}+.303 \mathrm{AM}+\varsigma 1$

After the model showed the compatibility (fit), making the coefficient decomposition, then, by counting direct effect, indirect effect, and the total effect of an exogenous variable on the endogenous variable. The total effect is direct effect plus an indirect effect. Those three things are shown in Table 5.

Table 4. The Summary of the Value Result of Path Coefficients

\begin{tabular}{ccccccc}
\hline No & Casual Relation & $\boldsymbol{t}$ statistics & $\boldsymbol{t}$ table & $\boldsymbol{p}$-values & Cut-off Sig. & Explanation \\
\hline 1 & $\mathrm{SC} \rightarrow \mathrm{AM}$ & 4.074 & 1.96 & .000 & .05 & Significant \\
2 & $\mathrm{SEE} \rightarrow \mathrm{AM}$ & 3.323 & 1.96 & .003 & .05 & Significant \\
3 & $\mathrm{SF} \rightarrow \mathrm{AM}$ & 3.067 & 1.96 & .004 & .05 & Significant \\
4 & $\mathrm{SA} \rightarrow \mathrm{AM}$ & 12.922 & 1.96 & .000 & .05 & Significant \\
5 & $\mathrm{SP} \rightarrow \mathrm{AM}$ & 2.211 & 1.96 & .011 & .05 & Significant \\
6 & $\mathrm{CGS} \rightarrow \mathrm{AM}$ & 3.082 & 1.96 & .005 & .05 & Significant \\
7 & $\mathrm{SC} \rightarrow \mathrm{ELA}$ & 2.605 & 1.96 & .009 & .05 & Significant \\
8 & $\mathrm{SEE} \rightarrow \mathrm{ELA}$ & 3.189 & 1.96 & .002 & .05 & Significant \\
9 & $\mathrm{SF} \rightarrow \mathrm{ELA}$ & 2.954 & 1.96 & .003 & .05 & Significant \\
10 & $\mathrm{SA} \rightarrow \mathrm{ELA}$ & 4.866 & 1.96 & .000 & .05 & Significant \\
11 & $\mathrm{SP} \rightarrow$ ELA & 2.506 & 1.96 & .013 & .05 & Significant \\
12 & $\mathrm{CGS} \rightarrow$ ELA & 2.601 & 1.96 & .010 & .05 & Significant \\
13 & $\mathrm{AM} \rightarrow$ ELA & 2.506 & 1.96 & .007 & .05 & Significant \\
\hline
\end{tabular}

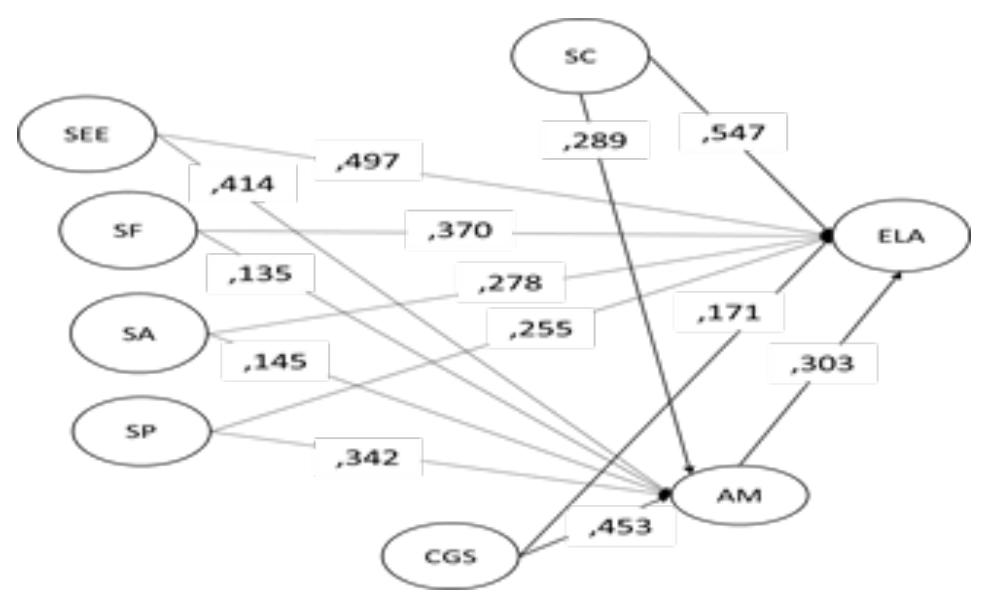

Figure 4. Path Coefficients 
Table 5. Direct, Indirect and Total Variable Effect

\begin{tabular}{lccc}
\hline \multirow{2}{*}{ Variable } & \multicolumn{3}{c}{ Effect } \\
\cline { 2 - 4 } & Direct & Indirect through AM & Total \\
\hline $\mathrm{SC} \rightarrow \mathrm{AM}$ & .289 & --- & .289 \\
$\mathrm{SEE} \rightarrow \mathrm{AM}$ & .414 & --- & .414 \\
$\mathrm{SF} \rightarrow \mathrm{AM}$ & .135 & --- & .135 \\
$\mathrm{SA} \rightarrow \mathrm{AM}$ & .145 & --- & .145 \\
$\mathrm{SP} \rightarrow \mathrm{AM}$ & .342 & --- & .342 \\
$\mathrm{CGS} \rightarrow \mathrm{AM}$ & .453 & --- & .453 \\
$\mathrm{SC} \rightarrow \mathrm{ELA}$ & .547 & .088 & .635 \\
$\mathrm{SEE} \rightarrow \mathrm{ELA}$ & .497 & .125 & .622 \\
$\mathrm{SF} \rightarrow \mathrm{ELA}$ & .370 & .041 & .411 \\
$\mathrm{SA} \rightarrow \mathrm{ELA}$ & .278 & .044 & .322 \\
$\mathrm{SP} \rightarrow$ ELA & .255 & .104 & .359 \\
$\mathrm{CGV} \rightarrow \mathrm{ELA}$ & .171 & .137 & .308 \\
$\mathrm{AM} \rightarrow$ ELA & .303 & --- & .303 \\
\hline
\end{tabular}

Based on Table 5, we can be seen the impact of direct and indirect effects among research variables. Those three things can be defined that direct effect based direct effect on figure 4 is the direct effect to $\mathrm{SC}$ on $\mathrm{AM}$ is showed by $\gamma \mathrm{SC} \cdot \mathrm{AM}=.289$, direct effect to SEE on $\mathrm{AM}$ is showed by $\gamma \mathrm{SEE}$. $\mathrm{AM}=.414$, direct effect to $\mathrm{SF}$ on $\mathrm{AM}$ is showed by $\gamma \mathrm{SF} . \mathrm{AM}=.135$, direct effect to SA on AM is showed by $\gamma$ SA.AM $=.145$, direct effect to $\mathrm{SP}$ on $\mathrm{AM}$ is showed by $\gamma \mathrm{SP} . \mathrm{AM}=.342$, and direct effect to CGS on AM is showed by $\gamma \mathrm{CGS}$.AM $=.453$.

Then, the amount of indirect effect which is showed the influence to SC on ELA through $\mathrm{AM}$ is showed by $\gamma \mathrm{SC}$.AM $\mathrm{x} \gamma \mathrm{AM} . \mathrm{ELA}=.088$, the influence to SEE on ELA through AM is showed by $\gamma$ SEE.AM x $\gamma$ AM.ELA $=.125$, the influence of SF on ELA through AM is showed by $\gamma$ SF.AM $\mathrm{x} \gamma$ AM.ELA $=.041$, the influence to SA on ELA through AM is showed by $\gamma \mathrm{SA}$. AM $x \gamma$ AM.ELA $=.044$, the influence to SP on ELA through AM is showed by $\gamma$ SP.AM $x \gamma$ AM. $\mathrm{ELA}=.104$ and the influence of CGS on ELA through AM is showed by $\gamma$ CGS.AM $\mathrm{x} \gamma \mathrm{AM}$. $\mathrm{ELA}=.137$.

\section{Hypotheses Test}

H1: the coefficient of SC on ELA getting the value of $t$ statistic is $2.605 \geq 1.96$, with $p$-Value or significant level .009, H2: the coefficient of SEE on ELA getting the value of $t$ statistic is $3.189 \geq 1.96$, with $p$-value or significant level .002 or less than $a=.05, \mathrm{H} 3$ : the coefficient of
SF on ELA getting the value of $t$ statistic is 2.954 $\geq 1.96$, with $p$-value or significant level .003 or less than $\mathrm{a}=.05(5 \%), \mathrm{H} 4$ : the coefficient of SA on ELA getting the value of $t$ statistic is 4.866 $\geq 1.96$, with $p$-value or significant level .000 or less than $a=.05$, H5: the coefficient of SP on ELA getting the value of $t$ statistic is $2.506 \geq$ 1.96 , with $p$-value or significant level .013 or less than $a=.05$, H6: the coefficient of CGS on ELA getting the value $t$ statistic is $2.601 \geq 1.96$, with $p$-value or significant level .010 or less than $a=.05$.

Then H7: the coefficient of AM on ELA getting the value of $t$ statistic is $2.506 \geq 1.96$, with $p$-value or significant level .013 or less than $a=.05, \mathrm{H} 8$ : there is a effect of SC on AM, that is $t$ stat value $=2.605>1.96$ with the sig value $<$ .05 , then, direct effect of AM on ELA, that, $t$ stat value $=2.506>1.96$ with sig value $<.05$, H9: there is effect of SEE on AM that is $t$ stat value $=3.323>1.96$ with sig value $<.05$, then, direct effect of AM on ELA that is $t$ stat $=2.506>1.96$ with sig value $<.05$, H10: there is a direct effect of SF on AM that is $t$ stat value $=3.067>1.96$ with sig value $<.05$, then, direct effect of AM on ELA that is $t$ stat value $=2.506>1.96$ with sig value <.05, H11: there is a direct effect of SA on AM that is $t$ stat value $=12.922>1.96$ with sig value $<.05$, then direct effect of AM on ELA that is $t$ stat value $=2.506>1.96$ with sig value $<.05, \mathrm{H} 12$ : there is a direct effect of SP on AM that is $t$ stat value $=2.211>1.96$ with sig value $<.05$, then, direct effect of AM on ELA that is $t$ 
stat value $=2.506>1.96$ with sig value $<.05$ and H13: there is direct effect of CGS on AM that is $t$ stat value $=3.082>1.96$ with sig value $<.05$, then, direct effect of AM on ELA that is $t$ stat $=$ $2.506>1.96$ with sig value $<.05$.

Furthermore, determinated coefficient of exogenous variables on endogenous variables $\left(R^{2}\right)$. Then, the total of $R^{2}$ value or determinated coefficient can be earned through data processing with SmartPLS 3.0 of each substructure to know the prediction of the mode. Determinated Coefficient among Research construct obtained are the structural model in Table 6.

\section{Discussion}

H1 clearly shows the value of $t$ statistic $>$ t table $(2.605>1.96)$ with $p=.009$. Besides the findings, there is path coefficient value among the implementation of SC on ELA is about .547 , and the correlation coefficient is about .608 which means there is a meaning in the effect among both latent variables. The finding is alike to Raharjo's findings in his research Raharjo (2014) that there is a significant effect among SC on ELA. Then, on $\mathrm{H} 2$ shows that the value of $t$ statistic $>t$ table $(3.189>1.96)$ with $p=.002$. Besides the findings, there is path coefficient value among the implementation of SEE on ELA is about .479 or the correlation is about .632 which means there is a meaning in the effect among both latent variables. The findings are alike to Raharjo (2014) which found that there is a significant effect between students' perception of the SEE on ELA. Then, Teachers have planned on Pedagogical practice integration on social justice, using Curriculum materials and parent-teacher meetings (Aguirre, Turner, Bartell, Kalinec-Craig, Foote, McDuffie \& Drake, 2013; Aguerre, Mayfield-Ingram \& Martin, 2013; Turner, Drake, McDuffie, Aguirre, Bartell, \& Foote, 2012; Bartell, Cho, Drake, Petchauer, \& Richmondal, 2019).
Based on this research, on $\mathrm{H} 3$ shows the value of $t$ statistic $>t$ table $(2.954>1.96)$ with $p=.003$. Besides the findings, there is path coefficient value among the implementation of SF on ELA is about .370 or the correlation is about .597 which means there is a meaning in the effect among both latent variables. The findings in line to Setiawan, Martono, \& Gunarhadi (2018); Odeh, Oguche, \& Dondo (2015); Suleman \& Hussain (2014); Adeogun \& Olisaemeka (2011); Asvio, Arpinus \& Suharmon (2017) wrote that there is a positive and significant effect in facility aspects and the school environment on ELA. Then according to Toha \& Wulandari (2016), social environment and administration staff can impact students' enthusiasm in learning.

Also, according to Raharjo in his research (2014), there is a significant effect among SF on ELA. Similarly, the finding of Mushtaq \& Khan (2012); Isa \& Yusoff (2015); O'Brennan, Bradshaw \& Furlong (2014) wrote that there is a significant correlation among the facility to the students' accomplishment or advancement through the learning process.

Based on this research, on $\mathrm{H} 4$ clearly shows the value of $t$ statistic $>t$ table (4.866 > $1.96)$ with $p=.000$. Besides the findings, there is path coefficient value among the implementation of SA on ELA is about 278 or the correlation is about .610 which means there is a meaning in the effect among both latent variables. The findings are alike to Raharjo (2014) wrote that there is a significant effect among standards of assessment towards students' achievement in learning.

Then, on $\mathrm{H} 5$ shows the value of $t$ statistic $>t$ table $(2.506>1.96)$ with $p=.013$. Besides this finding, there is path coefficient value among SP on ELA is about .255 or the correlation is about .515 which means there is a meaning in the effect among both latent variables. This finding supports the research of Akinoglu (2008); Raharjo (2014) said that there is a significant

Table 6. Determinated Coefficient

\begin{tabular}{|c|c|c|}
\hline The Structural Model & Equation of Structural Estimation & $R^{2}$ \\
\hline $\begin{aligned} \mathrm{X}_{7}= & \gamma_{17} \mathrm{X}_{1}+\gamma_{27} \mathrm{X}_{2}+\gamma_{37} \mathrm{X}_{3}+\gamma_{47} \mathrm{X}_{4} \\
& +\gamma_{57} \mathrm{X}_{5}+\gamma_{67} \mathrm{X}_{6}+\varsigma_{1}\end{aligned}$ & $\begin{aligned} \mathrm{X}_{7}=.289 \mathrm{X}_{1}+.414 \mathrm{X}_{2}+.135 \mathrm{X}_{3}+.145 \mathrm{X}_{4}+.342 \mathrm{X}_{5}+ \\
\quad .453 \mathrm{X}_{6}+\varsigma 1\end{aligned}$ & .601 \\
\hline $\begin{aligned} \mathrm{X}_{8}= & \gamma_{18} \mathrm{X}_{1}+\gamma_{28} \mathrm{X}_{2}+\gamma_{38} \mathrm{X}_{3}+\gamma_{48} \mathrm{X}_{4} \\
& +\gamma_{58} \mathrm{X}_{5}+\gamma_{68} \mathrm{X}_{6}+\gamma_{78} \mathrm{X}_{7}+\varsigma_{1}\end{aligned}$ & $\begin{aligned} \mathrm{X}_{8}= & .547 \mathrm{X}_{1}+497 \mathrm{X}_{2}+370 \mathrm{X}_{3}+.278 \mathrm{X}_{4}+.255 \mathrm{X}_{5}+ \\
& .177 \mathrm{X}_{6}+.303 \mathrm{X}_{7}+{ }^{1} 1\end{aligned}$ & .619 \\
\hline
\end{tabular}


effect among various learning including the indicators of SP on students' learning attitude including ELA.

Based on this research, H6 clearly shows the value of $t$ statistic $>t$ table $(2.601>1.96)$ with $p=.010$. Besides this finding, there is path coefficient value among SP on ELA is about .171 or the correlation is about .694 which means there is a meaning in the effect among both latent variables. This finding is alike to the Raharjo research (Raharjo, 2014) thought that there is a significant effect among CGS on ELA. Next, on $\mathrm{H} 7$ shows that the value $t$ statistic $>$ t table $(2.506$ $>1.96)$ with $p=.007$. Besides the findings, there is path coefficient value among AM on ELA is about .303 or the correlation is about .661 which means that there is a meaning in the effect of both latent variables. This finding proves that there is a direct and significant effect among the AM on ELA on the students of Senior High School. It shows that there is an improvement in ELA through AM. The resulting test is similar to than alike to the research of Cleopatra (2015); Tella (2007); Singh (2011) show the positive and significant effect among motivation towards learning achievement. In similar findings is on the research of Asvio et al. (2017) which means that there is positive and significant among AM on ELA.

On $\mathrm{H} 8$, there is a clearly indirect effect among SC on ELA through AM. It describes that the standard of content is positively influenced in AM to improve the students' achievement in the learning economy. $\mathrm{H} 9$ also shows that there is an indirect effect among SEE on ELA students through AM. SEE effected on AM (Gobena, 2018). It seems that AM obviously puts a good contribution to increasing ELA. Moreover, H10 explains that it provides the data that there is an indirect effect among SF on ELA through AM. Similarly, H11 says that there is an indirect effect among SA on ELA through AM. In addition, H12 tells that there is an indirect effect among SP on ELA through AM. Lastly, H13 shows that there is an indirect effect among CGS on ELA through AM. The entire hypothesis describing the new model, achievement motivation as a connecting media NSE on ELA, shows that there is a positive effect of motivation variable in running NSE as an effort in improving ELA. NSE familiarly can be influenced by AM in improving ELA. Therefore, to maximizing the ELA is necessarily shaped the AM both internally and externally. The AM which is in the students will result in the achievement of the NSE instrument as the main major for the Indonesian Government.

\section{CONCLUSION}

Finally, this research findings that there is a direct effect among SC on ELA and it directly impacts the ELA itself is about $54.7 \%$. Then there is a direct effect among SEE on ELA and it directly impacts the ELA itself is about $47.9 \%$. So, there is a direct effect among SF on ELA and it directly impacts the ELA itself is about $37 \%$. Next, there is a direct effect among SA on ELA and it directly impacts the ELA itself is about $27.8 \%$. In addition, there is a direct effect among SP on ELA and it directly impacts the ELA itself is about $25.5 \%$. Similarly, there is a direct effect among CGS on the ELA and it directly impacts the ELA itself is about $17.1 \%$. Furthermore, there is a direct effect among AM on ELA and it directly impacts the ELA itself is about $30.3 \%$.

Then, based on this research, there is an indirect effect among SC on ELA through AM. In addition, there is an indirect effect among SEE on ELA through AM. In similar, there is an indirect effect among SF on ELA through AM. Also, there is an indirect effect among SA on ELA through AM. Next, there is an indirect effect among SP on ELA through AM. And, there is an indirect effect among CGS on ELA through AM. Future research can be conducted by using a different mediation/moderation from this research. It is due to many types of research that have been conducted that there are many variables influencing students' achievement in the learning economy. The AM Variable can be shaped through many variables, the condition also becomes a big opportunity for the next research as a contribution or novelty research that can probably put an improvement or advancement in the coming education process.

\section{AKNOWLEDGMENTS}

I should like to thank the Editors of the journal of Cakrawala Pendidikan (CP) as well as the following reviewers who have generously given up valuable to review this paper. The success of this paper depends on their care and competence. Their conscientiousness is much appreciated. I also express my appreciation to all respondents who provided data. 


\section{REFERENCES}

Adeogun, A. A. \& Olisaemeka, B. U. (2011). Influences of school climate on students' achievement and teachers' productivity for sustainable development. Journal of US-China Education Review, 8(4), 552557. https://files.eric.ed.gov/fulltext/ ED520461.pdf.

Aguerre, J. M., Mayfield-Ingram, K., \& Martin, D. B. (2013). The impact of identity in $K-8$ mathematics: Rethinking equity-based practice. Reston, VA: Nation Council of Teachers of Mathematics.

Aguirre, J. M., Turner, E. E., Bartell, T. G., Kalinec-Craig, C. Foote, M. Q., McDuffie, A. R., \& Drake, C. (2013). Making connections in practice: Developing prospective teachers' capacities to connect children's mathematics thinking and community funds of knowledge in mathematics instruction. Journal of Teacher Education, 64(2), 178-192. doi:10.1177/0022487112466900.

Akinoglu, O. (2008). Assessment of the inquirybased project implementation process in science education upon students' points of views. International Journal of Instruction, 1(1), 1-12. http://www.e-iji. net/dosyalar/iji_2008_1_1.pdf.

Asvio, N., Arpinus, A., \& Suharmon, S. (2017). The influence of learning motivation and learning environment on undergraduate students' learning achievement of management of Islamic education, study program of IAIN Batusangkar In 2016. Noble International Journal of Social Sciences Research, 2(2), 16-31. http:// napublisher.org/ $\mathrm{ic}=$ journals\&id $=2$.

Bakhtiarvand, F., Ahmadiana, S., Delrooza, K., \& Delrooza, H. A. (2011). The moderating effect of achievement motivation on relationship of learning approaches and academic achievement. Procedia-Social and Behavioral Sciences, 28(2011), 486488. doi:10.1016/j.sbspro.2011.11.093.

Bartell, T., Cho, C., Drake, C., Petchauer, E., \& Richmond, G. (2019). Teacher agency and resilience in the age of neoliberalism.
Journal of Teacher Education, 70(4), 302305. doi:10.1177/0022487119865216.

Bussmaker,M.,Trokanas,N.,\&Cecelja,F.(2017). An ontological approach to chemical engineering curriculum development. Computers and Chemical Engineering, 106, 927-941-21. doi:10.1016/j. compchemeng.2017.02.021.

Cleopatra, M. (2015). Pengaruh gaya hidup dan motivasi belajar terhadap prestasi belajar matematika. [The influence of lifestyle and learning motivation on mathematics learning achievement]. Jurnal Formatif, 5(2), 168-181. doi:10.30998/formatif. v5i2.336.

Corpus, J. H., McClintic-Gilbert, M. S., \& Hayenga, A. O. (2009). Within-year changes in children's intrinsic and extrinsic motivational orientations: Contextual predictors and academic outcomes. Contemporary Educational Psychology, 34(2), 154-166. doi:10.1016/j. cedpsych.2009.01.001.

Gobena, G.A. (2018). Factors affecting in-service teachers' motivation: Its implication to quality of education. International Journal of Instruction, 11(3), 163-178. doi:10.12973/iji.2018.11312a.

Hardin, H., Mustari, L. O. M., \& Sari, W. (2019). The effect of achievement motivation, fear of success on the performance of farming women in Ngkaringkaring Village, Baubau City. International Journal of Management Progress, 1(1), 10-21. doi:10.35326/ijmp.v1i1.407.

Hargreaves, A. \& Moore, S. (2000). Curriculum integration and classroom Relevance: A study of teacher practice. Journal of Curriculum and Supervision, 15(2), 89112. https://eric.ed.gov/?id=EJ598992.

Hargreaves, E. (2017). Children's experiences of classrooms: Talking about being pupils in the classrooms. London: Sage.

Haryono, S. (2017). Metode SEM untuk penelitian manajemen AMOS LISREL PLS. [SEM method for management 
research AMOS LISREL PLS]. Jakarta Timur: Luxima Metro Media.

Hopkins, E. A. (2008). Classroom conditions to secure enjoyment and achievement: pupils' voice listening to the voice of every child matters. Education 3-13, 36(4), 393401. doi:10.1080/03004270801969386.

Hosnan, M. (2016). Pendekatan saintifik dan kontekstual dalam pembelajaran Abad 21. [Scientific and contextual approach in $21^{\text {st }}$ Century Learning]. Bogor: Ghalia Indonesia.

Isa, A. \& Yusoff, W. Z. (2015). State of physical facilities of higher education institutions in Nigeria. International Journal of Scientific and Research Publications, 5(4), 1-5. http://www.ijsrp.org/researchpaper-0415/ijsrp-p4026.pdf.

Kurniasih, I. \& Sani, B. (2014). Implementasi Kurikulum 2013 konsep dan penerapan. [Implementation of Curriculum 2013 concept and implementation]. Surabaya: Kata Pena

Manyukhina, Y. \& Wyse, D. (2019). Learner agency and the curriculum: A critical realist perspective. The Curriculum Journal, 30(3), 223-243. doi:10.1080/095 85176.2019 .1599973$.

McClelland, D. C. (1985). Human motivation. Chicago: Scott Foresman.

Moss, J. \& Harvie, K. (2015). Cross-curriculum design: Enacting inclusive pedagogy and curriculum. Inclusive Pedagogy across the Curriculum, 7, 259-279. doi:10.1108/ S1479-363620150000007018.

Mulyasa, E. (2014). Pengembangan dan implementasi Kurikulum 2013: Perubahan dan pengembangan Kurikulum 2013 merupakan persoalan penting dan genting. [Curriculum development and implementation 2013: The change and development of Curriculum 2013 is an important and critical issue]. Bandung: Remaja Rosdakarya.

Mushtaq, I.\& Khan, S.N.(2012). Factors affecting students' academic performance. Global Journal of Management and Business, 12(9), 17-22. https://globaljournals.org/ GJMBR_Volume12/3-Factors-AffectingStudents-Academic.pdf.

O’Brennan, L. M., Bradshaw, C. P. \& Furlong, M. J. (2014). Influence of classroom and school climate on teacher perceptions of student problem behavior. School Mental Health, 6(2), 125-136. doi:10.1007/ s12310-014-9118-8.

Odeh, R. C., Oguche, O. A. \& Dondo, I. E. (2015). Influence of school environment on academic achievement of students in secondary schools in zone "A" Senatorial District of Benue State, Nigeria. International Journal of Recent Scientific Research, 6(7), 4914-4922. http:// www.recentscientific.com/sites/default/ files/2746.pdf.

Ornstein, A. C. \& Hunkins, F. P. (2013). Curriculum foundations, principles, and issues. New Jersey, NJ: Person.

Papilaya, J., Tuakora, P., \& Rijal, M. (2019). Compensation, transparency, and motivation effects on the performance of junior high school teachers in Western Seram, Indonesia. International Journal of Instruction, 12(3), 439-458. doi:10.29333/ iji.2019.12327a.

Poerwati, L .E. \& Amri, S. (2013). Panduan memahami kurikulum 2013. [Guide to understanding Curriculum 2013]. Jakarta: Prestasi Pustaka.

Raharjo, S. B. (2014). Contribution of eight national education standards towards learning achievement. Jurnal Pendidikan dan Kebudayaan, 20(4), 470-482. doi:10.24832/jpnk.v20i4.160.

Robinson, C. (2014) Children, their voices and their experiences of school: What does the evidence tell us? New York, NY: Cambridge Primary Review Trust.

Robinson, C., \& Fielding, M. (2010). Children and their primary schools: Pupils' voices. In R. Alexander (Ed.). The Cambridge 
primary review research surveys. New York, NY: Routledge, pp. 17-48.

Sari, A. P. \& Setiawan, A. (2018). The development of internet-based economic learning media using moodle approach. International Journal of Active Learning, $3(2), \quad 100-109$. doi:10.15294/ijal. v3i2.13449.

Saylor, J. G \& Alexander, W. (1974). Planning curriculum for schools. New York, NY: Appleton Century Crofs, Inc.

Setiawan, A., Martono, T. \& Gunarhadi. (2018). The analysis of learning infrastructure (LI), learning motivation (LM) and economics learning achievement (ELA). Journal of Education and Learning (EduLearn), 12(2), 236-243. doi:10.11591/edulearn. v12i2.8124.

Shawer, S. F. (2017). Teacher-driven curriculum development at the classroom level: Implications for curriculum, pedagogy and teacher training. Teaching and Teacher Education, 63(2017), 296-313. doi:10.1016/j.tate.2016.12.017.

Short, E. C. (1987). Curriculum decision making in teacher education: Policies, program development, and design. Journal of Teacher Education, 38(4), 2-12. doi:10.1177/002248718703800402.

Singh, K. (2011). Study of achievement motivation in relation to academic achievement of students. International Journal of Educational Planning \& Administration, 1(2), 161-171. http:// www.ripublication.com/ijepa.htm.

Suleman, Q. \& Hussain, I. (2014). Effects of classroom physical environment on the academic achievement scores of secondary school students in Kohat Division, Pakistan. International Journal of Learning \& Development, 4(1), 71-82. doi:10.5296/ijld.v4i1.5174.

Tella, A. (2007). The impact of motivation on student's academic achievement and learning outcomes in mathematics among secondary school. EURASIA, 3(2), 149156. doi:10.12973/ejmste/75390.

Toha, I. \& Wulandari, D. (2016). The effect of parent attention and learning discipline on economics learning outcomes. IOSR Journal of Research \& Method in Education (IOSR-JRME), 6(2), 100-104. doi:10.9790/7388-060201100104.

Tucker, C. M., Zayco, R. A., \& Herman, K. C. (2002). Teacher and child variables as predictors of academic engagement among low-income African American children. Psychology in the Schools, 39(4), 477-488. doi:10.1002/pits.10038.

Turner, E. E., Drake, C., McDuffie, A. R., Aguirre, J., Bartell, T. G., \& Foote, M. Q. (2012). Promoting equity in mathematics teacher preparation: A framework for advancing teacher learning of children's multiple mathematics knowledge bases. Journal of Mathematics Teacher Education, 15(1), 67-82. doi:10.1007/s10857-011-9196-6.

Uno, B. H., Masri, K., \& Panjaitan, K. (2014). Variabel penelitian dalam pendidikan dan pembelajaran. [Variable research in education and learning]. Jakarta: PT Ina Publikatama.

Winkel, W. S. (2004). Psikologi pendidikan dan evaluasi belajar. [Educational psychology and learning evaluation]. Jakarta: Gramedia.

Wood, D. \& Graham, S. (2015). Why race matters: Social context and achievement motivation in African American youth. Advances in Motivation and Achievement, 16B, 175-209. doi:10.1108/S07497423(2010)000016B009. 
Appendix 1. The Grid of Research Instrument

The Grid of Standard of Content (SC)

\begin{tabular}{llcc}
\hline Dimension & Indicator & Item & Code \\
\hline $\begin{array}{l}\text { Appropriate } \\
\text { and relevant } \\
\text { Curriculum }\end{array}$ & $\begin{array}{l}\text { The Curriculum is made by considering local } \\
\text { characteristic } \\
\text { The Curriculum is made by considering the social needs } \\
\text { in society } \\
\begin{array}{l}\text { The Curriculum is made by considering the learning } \\
\text { needs }\end{array}\end{array}$ & 2 & SC_001 \\
$\begin{array}{l}\text { The Curriculum has showed the remedial program plan } \\
\text { School provides a service of guidance and counceling }\end{array}$ & 4 & SC_003 \\
$\begin{array}{l}\text { School provides the } \\
\text { needs of students' } \\
\text { improvement }\end{array}$ & $\begin{array}{l}\text { School provides ex-school to meet the students' needs } \\
\text { Source: Government regulation number 32 in 2013, Poerwati \& Amri (2013) }\end{array}$ & SC_005 \\
\end{tabular}

The Grid of Standard of Educator and Education Staff (SEE)

\begin{tabular}{llcc}
\hline \multicolumn{1}{c}{ Dimension } & Indicator & Item & Code \\
\hline Competency and & Good personality & 7 & SEE_001 \\
Adequated education & Prestigious & 8 & SEE_002 \\
& Good economy mastery & 9 & SEE_003 \\
Competency of & Maximum service & 10 & SEE_004 \\
education staff & To be able to communicate well & 11 & SEE_005 \\
& Good chararacter & 12 & SEE_006 \\
\hline
\end{tabular}

Source: Government regulation number 32 in 2013, Poerwati \& Amri (2013)

The Grid of Standard of Facility (SF)

\begin{tabular}{|c|c|c|c|}
\hline $\begin{array}{r}\text { Dimension } \\
\text { School facility is } \\
\text { already qualified }\end{array}$ & Indicator & Item & Code \\
\hline \multirow[t]{4}{*}{$\begin{array}{l}\text { School facility is } \\
\text { already qualified }\end{array}$} & $\begin{array}{l}\text { School standard is already good for the total of the } \\
\text { room }\end{array}$ & 13 & SF_001 \\
\hline & Requirements for ventilation system & 14 & SF_002 \\
\hline & $\begin{array}{l}\text { School standard is already good for the learning } \\
\text { instrument }\end{array}$ & 15 & SF_003 \\
\hline & $\begin{array}{l}\text { School is already good for the books in learning } \\
\text { process }\end{array}$ & 16 & SF_004 \\
\hline $\begin{array}{l}\text { School in maintained } \\
\text { and good condition }\end{array}$ & The school building is safe & 17 & SF_005 \\
\hline
\end{tabular}

\section{The Grid of Standard of Assessment (SA)}

\begin{tabular}{|c|c|c|c|}
\hline \begin{tabular}{l}
\multicolumn{1}{c}{ Dimension } \\
The assessment impacts to \\
learning process
\end{tabular} & Indicator & Item & Code \\
\hline \multirow{5}{*}{$\begin{array}{l}\text { The assessment impacts to } \\
\text { learning process }\end{array}$} & Teacher gives suggestion for the students. & 18 & SA 001 \\
\hline & Teacher puts comments on the students & 19 & $\mathrm{SA}^{-} 002$ \\
\hline & Teacher uses the assessment result to better learning & 20 & SA_003 \\
\hline & $\begin{array}{l}\text { Students are motivated to study hard by the } \\
\text { assessment given by the teacher }\end{array}$ & 21 & SA_004 \\
\hline & $\begin{array}{l}\text { The teacher's assessment is so useful for the } \\
\text { learning process }\end{array}$ & 22 & SA_005 \\
\hline $\begin{array}{l}\text { The students' parents } \\
\text { involve in their children's } \\
\text { learning process }\end{array}$ & $\begin{array}{l}\text { School reports the result of the whole lesson in } \\
\text { the end of the semester to the students' parents in } \\
\text { education book report }\end{array}$ & 23 & SA_006 \\
\hline
\end{tabular}


The Grid of Standard of Process (SP)

\begin{tabular}{|c|c|c|c|}
\hline Dimension & Indicator & Item & Code \\
\hline \multirow{4}{*}{$\begin{array}{l}\text { The sources in learning } \\
\text { is able to be acquired } \\
\text { easily and used properly }\end{array}$} & $\begin{array}{l}\text { Students can access other learning source aside } \\
\text { from the school book }\end{array}$ & 24 & SP_001 \\
\hline & Teacher uses guidance book in teaching & 25 & SP_002 \\
\hline & $\begin{array}{l}\text { Teacher uses the other sources beside school } \\
\text { book }\end{array}$ & 26 & SP_003 \\
\hline & Teacher motivates the students & 27 & SP_004 \\
\hline \multirow{4}{*}{$\begin{array}{l}\text { The learning process is } \\
\text { done by usig interactive } \\
\text { learning method }\end{array}$} & $\begin{array}{l}\text { Teacher does the learning process based on } \\
\text { interactive lesson plan }\end{array}$ & 28 & SP_005 \\
\hline & $\begin{array}{l}\text { Teacher delivers the goal of the learning process } \\
\text { in the beginning }\end{array}$ & 29 & SP_006 \\
\hline & $\begin{array}{l}\text { Students have a same chance to explore the } \\
\text { learning }\end{array}$ & 30 & SP_007 \\
\hline & Students have a same chance to do confirmation & 31 & SP_008 \\
\hline
\end{tabular}

The Grid of Competence Graduate Standard (CGS)

\begin{tabular}{llcc}
\hline \multicolumn{1}{c}{ Dimension } & \multicolumn{1}{c}{ Indicator } & Item & \multicolumn{1}{c}{ Code } \\
\hline $\begin{array}{l}\text { Students are able to } \\
\text { achieve the goal of } \\
\text { learning }\end{array}$ & $\begin{array}{l}\text { Students show the better improvement after } \\
\text { the process in learning economy } \\
\text { Students show the improvement as } \\
\text { independent learners } \\
\text { Students show a high self confidence }\end{array}$ & 32 & CGS_001 \\
$\begin{array}{ll}\text { Students are able to } \\
\text { develop their talent as } \\
\text { society member }\end{array}$ & $\begin{array}{l}\text { School develops the students' personality } \\
\text { School develops life skills }\end{array}$ & CGS_002 \\
Source: Government regulation number 32 in 2013, Mulyasa (2014) & CGS_003 & CGS_004 \\
\hline
\end{tabular}

The Grid of Achievement Motivation (AM)

\begin{tabular}{llcc}
\hline \multicolumn{1}{c}{ Dimension } & \multicolumn{1}{c}{ Indicator } & Item & \multicolumn{1}{c}{ Code } \\
\hline Responsibility & The work can be done on schedule & 37 & AM_001 \\
Confidence & Believe in facing the challenge & 38 & AM_002 \\
Risk taker & Brave in taking descision & 39 & AM_003 \\
Feedback & Corporate with others & 40 & AM_004 \\
Inovation & Inovating in problem solving & 41 & AM_005 \\
& Inovating in daily & 42 & AM_006 \\
\hline Source: Uno, Masri, \& Panjaitan (2014)
\end{tabular}

The Grid of Economics Learning Achievement (ELA)

\begin{tabular}{llcl}
\hline \multicolumn{1}{c}{ Dimension } & \multicolumn{1}{c}{ Indicator } & Item & \multicolumn{1}{c}{ Code } \\
\hline Achievement in learning & The value of knowledge economic & 43 & ELA_001 \\
Economy & The value attitude & 44 & ELA_002 \\
& The value skill & 45 & ELA_003 \\
\hline Source: Bussmaker at al. (2017), Kurniasih \& Sani (2014)
\end{tabular}


Appendix 2. Construct Result of Output Cross Loading

\begin{tabular}{|c|c|c|c|c|c|c|c|c|}
\hline Code & SC & SEE & SF & SA & SP & CGS & $\mathbf{A M}$ & ELA \\
\hline SC_001 & .774 & .403 & .477 & .294 & .304 & .480 & .534 & .431 \\
\hline SC_002 & .615 & .391 & .284 & .276 & .296 & .356 & .292 & .371 \\
\hline SC 003 & .818 & .524 & .540 & .373 & .329 & .615 & .601 & .546 \\
\hline SC_004 & .771 & .393 & .477 & .285 & .307 & .473 & .513 & .437 \\
\hline SC_005 & .609 & .375 & .278 & .257 & .287 & .336 & .295 & .364 \\
\hline SC_006 & .808 & .480 & .512 & .372 & .332 & .584 & .574 & .507 \\
\hline SEE_001 & .516 & .804 & .545 & .462 & .461 & .694 & .566 & .609 \\
\hline SEE_002 & .459 & .817 & .375 & .299 & .281 & .514 & .606 & .450 \\
\hline SEE_003 & .509 & .821 & .357 & .278 & .247 & .539 & .591 & .472 \\
\hline SEE_004 & .499 & .802 & .541 & .455 & .435 & .664 & .550 & .602 \\
\hline SEE_005 & .428 & .805 & .344 & .321 & .285 & .497 & .558 & .431 \\
\hline SEE_006 & .489 & .822 & .344 & .284 & .223 & .536 & .546 & .471 \\
\hline SF_- 001 & .484 & .431 & .748 & .273 & .288 & .523 & .473 & .447 \\
\hline SF_002 & .341 & .280 & .702 & .172 & .193 & .393 & .317 & .376 \\
\hline SF_003 & .465 & .454 & .796 & .348 & .313 & .534 & .466 & .504 \\
\hline SF_004 & .422 & .282 & .719 & .267 & .311 & .414 & .328 & .404 \\
\hline SF_005 & .464 & .482 & .795 & .386 & .380 & .626 & .484 & .495 \\
\hline SA_001 & .425 & .430 & .405 & .849 & .542 & .539 & .456 & .578 \\
\hline SA_002 & .381 & .376 & .371 & .904 & .632 & .488 & .386 & .559 \\
\hline SA_003 & .309 & .325 & .235 & .836 & .581 & .394 & .338 & .443 \\
\hline SA_004 & .415 & .432 & .407 & .847 & .529 & .546 & .454 & .576 \\
\hline SA_005 & .360 & .378 & .368 & .901 & .624 & .486 & .386 & .546 \\
\hline SA_006 & .283 & .323 & .226 & .831 & .567 & .390 & .325 & .425 \\
\hline SP_001 & .499 & .586 & .406 & .308 & .726 & .589 & .270 & .471 \\
\hline SP_002 & .396 & .379 & .488 & .385 & .665 & .407 & .350 & .442 \\
\hline SP_003 & .487 & .536 & .485 & .472 & .797 & .549 & .490 & .522 \\
\hline SP_004 & .456 & .448 & .574 & .429 & .763 & .512 & .443 & .506 \\
\hline SP_005 & .523 & .576 & .476 & .465 & .787 & .588 & .436 & .565 \\
\hline SP_006 & .528 & .626 & .553 & .409 & .771 & .623 & .379 & .582 \\
\hline SP_007 & .495 & .545 & .536 & .429 & .709 & .548 & .347 & .530 \\
\hline SP_008 & .435 & .434 & .381 & .303 & .560 & .519 & .256 & .376 \\
\hline CGS _001 & .561 & .566 & .516 & .403 & .689 & .786 & .363 & .550 \\
\hline CGS_002 & .389 & .498 & .391 & .328 & .479 & .729 & .270 & .373 \\
\hline CGS_003 & .383 & .371 & .312 & .214 & .410 & .589 & .248 & .367 \\
\hline CGS_004 & .431 & .532 & .325 & .297 & .504 & .650 & .246 & .373 \\
\hline CGS_005 & .471 & .412 & .348 & .298 & .443 & .663 & .293 & .408 \\
\hline $\mathrm{AM} \_001$ & .429 & .424 & .417 & .684 & .528 & .431 & .981 & .530 \\
\hline AM_002 & .408 & .408 & .382 & .632 & .493 & .420 & .968 & .506 \\
\hline AM_003 & .410 & .409 & .392 & .649 & .505 & .400 & .973 & .489 \\
\hline AM_004 & .404 & .405 & .393 & .664 & .509 & .411 & .980 & .503 \\
\hline AM_005 & .388 & .372 & .385 & .648 & .487 & .377 & .956 & .486 \\
\hline AM_006 & .372 & .339 & .357 & .605 & .463 & .373 & .928 & .467 \\
\hline ELA_001 & .554 & .581 & .552 & .551 & .671 & .574 & .488 & .871 \\
\hline ELA_002 & .508 & .503 & .484 & .521 & .555 & .481 & .442 & .866 \\
\hline ELA_003 & .506 & .548 & .505 & .502 & .560 & .519 & .398 & .849 \\
\hline
\end{tabular}

The Effect of Curriculum 2013 on Economics Learning Achievement: ... 